\title{
Serum 25-hydroxy-vitamin D in hepatobiliary disease in infancy
}

\author{
AKIO KOBAYASHI, SAKAE KAWAI, MICHIKO OHKUBO, AND YOSHIRO OHBE \\ Department of Paediatrics, National Children's Hospital, Tokyo
}

SUMMARY Serum 25-hydroxy-vitamin D (25-OHD) concentrations were measured in 49 patients with hepatobiliary disease in infancy. Low mean values were found in groups of patients with biliary atresia, neonatal hepatitis, choledochal cyst, and chronic intrahepatic cholestatic syndrome. In the group of patients with surgically repaired biliary atresia, the mean value did not differ from normal. Parenteral vitamin D increased 25-OHD in serum in patients with biliary atresia, but did not do so in one patient with neonatal hepatitis. In contrast, oral vitamin D did not increase serum 25-OHD concentrations in patients with biliary atresia. It is concluded that the reduction of serum 25-OHD seen in biliary atresia was largely due to the malabsorption of vitamin $\mathrm{D}$, while in neonatal hepatitis it was due to impairment of 25-hydroxylation of the vitamin.

Although rickets is a common complication in hepatobiliary disease in infancy (Yu et al., 1971; Kobayashi et al., 1974a), the mechanism underlying its pathogenesis is poorly understood. It can be postulated that the impairment of 25-hydroxylation of vitamin $\mathrm{D}$ in the liver may contribute to the pathogenesis of hepatic rickets. On the other hand, rickets in hepatobiliary disease may result from defective absorption of fat-soluble vitamin $\mathbf{D}$ because of deficient or absent bile flow into the intestine. The present study was undertaken to assess serum 25-hydroxy-vitamin D (25-OHD) concentrations in patients with hepatobiliary disease in infancy and to investigate the pathogenesis of hepatic rickets.

\section{Subjects and methods}

The subjects were 14 patients with biliary atresia, 22 with biliary atresia who had been successfully repaired by hepatic portojejunostomy and had no jaundice (Kobayashi et al., 1976), 7 infants with neonatal hepatitis, 5 patients with chronic intrahepatic cholestatic syndrome, and one infant with choledochal cyst.

All patients with biliary atresia had laparotomy

Department of Paediatrics, Section of Gastroenterology, National Children's Hospital, Tokyo

AKIO KOBAYASHI, clinical paediatrician

SAKAE KAWAI, clinical paediatrician

MICHIKO OHKUBO, clinical paediatrician

YOSHIRO OHBE, chief clinical paediatrician and the diagnosis was confirmed. Diagnosis of neonatal hepatitis was on clinical and laboratory grounds, excluding other diseases causing obstructive jaundice during infancy. Of 5 patients with chronic intrahepatic cholestatic syndrome, 3 had intrahepatic biliary hypoplasia (Alagille et al., 1975) and the other 2 had recurrent intrahepatic cholestasis (Summerskill and Walshe, 1959). One infant with choledochal cyst had a laparotomy and the diagnosis was confirmed.

Radiological evidence of rickets was found in $7(50 \%)$ of 14 patients with biliary atresia at the time of determination of serum 25-OHD. No lesions were observed in 22 patients with surgically repaired biliary atresias. In neonatal hepatis $3(43 \%)$ of 7 patients had the lesion. In the group of patients with chronic intrahepatic cholestatic syndrome one patient with intrahepatic biliary hypoplasia had rickets. The infant with choledochal cyst had no radiological signs of rickets. The lesions in the present series were florid.

Serum 25-OHD was measured by a modified method of Belsey et al. (1974), using competitive protein-binding assay.

\section{Results}

Serum 25-OHD concentrations of control group. Serum 25-OHD was measured in 17 healthy infants and children. The mean value from age 2 months to $111 / 12$ years was $22 \cdot 4 \mathrm{ng} / \mathrm{ml}(\mathrm{n}=11$, SD $9 \cdot 5)$, with a range of $8 \cdot 3$ to $42 \cdot 0$. In the group above 2 
years of age it was $18.9 \mathrm{ng} / \mathrm{ml}(\mathrm{n}=6$, SD 7.6), with a range of 12.5 to $30 \cdot 0$. There was no significant difference between the two age groups.

Serum 25-OHD concentrations in hepatobiliary disease (Fig. 1). In 14 patients with biliary atresia serum 25-OHD concentrations were conspicuously reduced with the mean value of $8 \cdot 2 \mathrm{ng} / \mathrm{ml}$ (SD $5 \cdot 2$, range $2 \cdot 0$ to $17 \cdot 5$ ), which was significantly lower than normal $(\mathrm{P}<0.001)$. In contrast, the mean serum 25-OHD value for 22 patients with successfully repaired biliary atresia was $23.5 \mathrm{ng} / \mathrm{ml}$ (SD $11 \cdot 0$, range $6 \cdot 0$ to $43 \cdot 5$ ). The value was not significantly different from normal. In neonatal hepatitis the value was reduced to the same extent as in biliary atresia, with a mean of $9 \cdot 2 \mathrm{ng} / \mathrm{ml}$ (SD $5 \cdot 3$, range $2 \cdot 0$ to $14 \cdot 5)$. In chronic intrahepatic cholestatic syndrome serum 25-OHD was very low, with a mean of $6 \cdot 4 \mathrm{ng} / \mathrm{ml}$ (SD 5.9, range $2 \cdot 0$ to $16 \cdot 5$ ). Patients with rickets generally showed low serum 25-OHD concentrations, while those whose serum levels were very low not always had radiological evidence of rickets. However, some of these patients with very low levels of serum 25-OHD and without rickets at the time of determination of serum 25-OHD, later showed radiological signs of rickets.

Effect of vitamin D on serum 25-OHD in hepatobiliary disease (Fig. 2). The effect of oral and parenteral vitamin D on serum 25-OHD was evaluated in 6

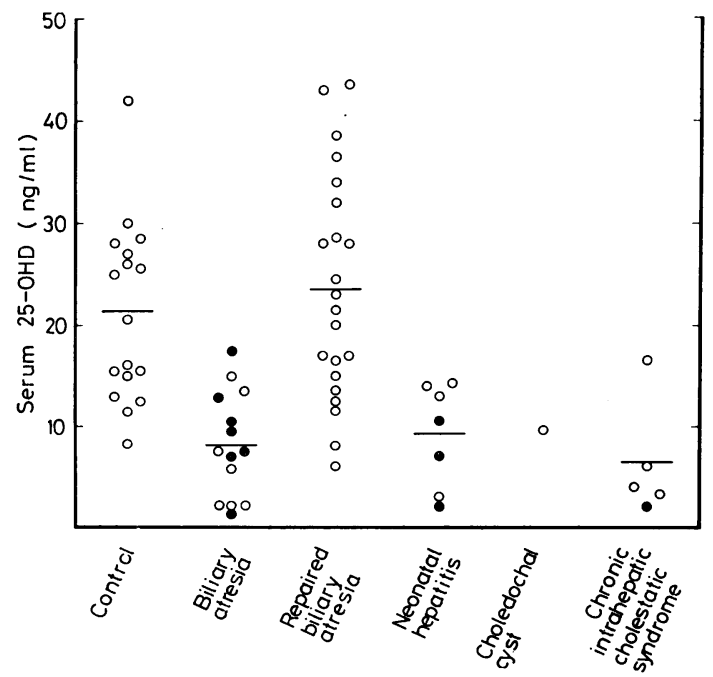

Fig. 1 Serum 25-OHD concentration in hepatobiliary disease in infancy. Solid circles (๑) indicate patients with rickets and open circles (O) those without the lesion. patients with biliary atresia. In 2 infants who had been given oral vitamin D 3000 IU daily, one for 2 and the other for 5 weeks, serum 25-OHD concentration did not change significantly $(10 \cdot 5$ to $7 \cdot 0$, 13.5 to $13.5 \mathrm{ng} / \mathrm{ml}$ ). In contrast, in 4 patients who had been given IM vitamin D 30000 IU weekly for 2 to 12 weeks, serum 25-OHD concentration was enhanced, markedly in $2(2 \cdot 0$ to $48 \cdot 0,7 \cdot 5$ to $27 \cdot 0$ $\mathrm{ng} / \mathrm{ml})$ and mildly in the other $2(7 \cdot 0$ to $11 \cdot 0,15 \cdot 0$ to $18 \cdot 0 \mathrm{ng} / \mathrm{ml}$ ).

The effect of parenteral vitamin $\mathbf{D}$ on serum 25-OHD was evaluated in one infant with neonatal hepatitis in whom serum concentration before treatment was $2 \cdot 0 \mathrm{ng} / \mathrm{ml}$. On admission the patient suffered from tetany and haemorrhagic diathesis, while the stools were yellow in colour and serum bilirubin was $7.0 \mathrm{mg} / 100 \mathrm{ml}(120 \mu \mathrm{mol} / \mathrm{l})$. Serum 25-OHD was not raised, despite IM vitamin D $50000 \mathrm{IU}$ weekly for 2 weeks.

Comparative biochemical studies in hepatobiliary disease. The levels of serum alkaline phosphatase, calcium, magnesium, and phosphorus in each group were studied. Serum alkaline phosphatase level was raised in most patients with biliary atresia, neonatal hepatitis, or chronic intrahepatic cholestatic syndrome, and it was also raised in half of the patients with repaired biliary atresia. There was, however, no correlation between serum 25-OHD and alkaline phosphatase. Serum calcium levels were within the normal range in most patients with the

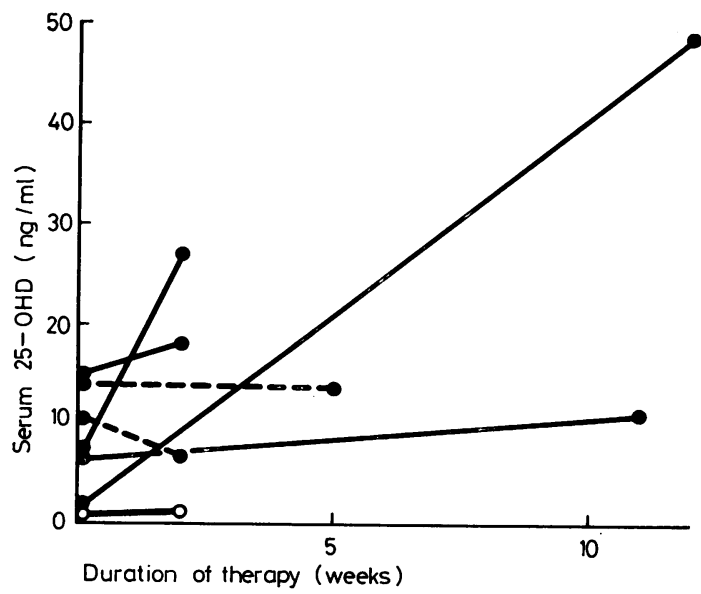

Fig. 2 Serum 25-OHD concentrations in 6 patients with biliary atresia ( $)$ and one with neonatal hepatitis $(O)$ before and after treatment with oral (dotted lines) and parenteral (solid lines) vitamin $D$. 
exception of 3 with biliary atresia, one with repaired biliary atresia, one with neonatal hepatitis, and one with intrahepatic biliary hypoplasia. Concentrations of phosphorous were within the normal range in all groups.

Serum 25-OHD did not correlate with any conventional liver function tests performed on these infants.

\section{Discussion}

There have been several reports on serum 25-OHD concentrations in adult patients with hepatobiliary disease, and the value is usually low (Haddad and Chyu, 1971; Hepner et al., 1976; Long et al., 1976; Wagonfeld et al., 1976; Long et al., 1978). However, we are unaware of any previous systematic survey of serum 25-OHD in infants with hepatobiliary disease. The present study showed low serum 25-OHD level in hepatobiliary disease in infancy, including biliary atresia, neonatal hepatitis, choledochal cyst, and chronic intrahepatic cholestatic syndrome. In biliary atresia, in which bile flow into the gut is absent, serum level was conspicuously reduced. In surgically repaired biliary atresia the value was enhanced to the normal range. In both neonatal hepatitis and chronic intrahepatic cholestatic syndrome serum 25-OHD was reduced to the same extent as in biliary atresia.

In the report by Daum et al. (1976), who studied serum 25-OHD in 5 cases of biliary atresia, the value ranged from 2 to $7 \mathrm{ng} / \mathrm{ml}$. One case showed a normal level after surgical repair of biliary atresia despite the presence of secondary biliary cirrhosis. Their results were in general in accord with ours, but the range of the value in the present series was greater.

Our study showed that impaired 25-hydroxylation of vitamin D did not account for the low level of 25-OHD in biliary atresia, as serum 25-OHD was distinctly raised in at least 2 of 4 patients with biliary atresia who had received parenteral vitamin $\mathbf{D}$. On the other hand, serum 25-OHD was not raised by treatment with oral vitamin $D$. These findings suggest that low serum level of 25-OHD observed in biliary atresia was attributable to the malabsorption of vitamin D rather than to the impairment of 25-hydroxylation of the vitamin. This conclusion accords with our previous report on the intestinal absorption of calcium and magnesium in hepatobiliary disease in infancy (Kobayashi et al., 1974b). In the paper, it was shown that in biliary atresia parenteral vitamin $\mathbf{D}$ increased moderately the absorption of both elements, although oral vitamin $D$ had little effect.

Rickets is a common complication in neonatal hepatitis (Yu et al., 1971; Kobayashi et al., 1974a), in which the malabsorption of calcium and magnesium has also been shown (Kobayashi et al., 1974b). The present report showed a low serum level of 25-OHD in patients with the disease. The mechanisms underlying the pathogenesis of rickets in neonatal hepatitis, however, were different from those in biliary atresia. The impaired 25-hydroxylation of vitamin $\mathbf{D}$ may be responsible for the development of rickets in neonatal hepatitis to a greater extent than the malabsorption of vitamin $\mathrm{D}$, as the present study showed that one infant who had been treated with parenteral vitamin $\mathbf{D}$ still had a low serum level of 25-OHD. This mechanism was also suggested by Antony and Beveridge (1975), who stressed the prematurity of infants with neonatal hepatitis. They stated that the small fat tissue and muscle mass of premature infants, the sites of storage for vitamin $D$, and the immaturity of hepatic enzymes in combination with hepatitis might have a role in the development of rickets.

From this study, and the previous one, it is reasonable to treat patients with rickets and biliary atresia with intramuscular vitamin D 30000 IU weekly. In contrast, oral vitamin D is sufficient in mild or moderate cases of neonatal hepatitis in a dose of 2000 to $5000 \mathrm{IU}$ daily for several weeks (Yu et al., 1971), while infants with severely damaged liver parenchyma need oral 25-OHD, a more potent metabolite of vitamin D (Burmeister et al., 1972; Daum et al., 1976; Wagonfeld et al., 1976).

We thank Professor T. Suda, Department of Biochemistry, Showa University School of Dentistry, for measurement of serum 25-OHD. This study was supported by the fourth Mitsukoshi Medical Award.

\section{References}

Alagille, D., Odièvre, M., Gautier, M., and Dommergues, J. P. (1975). Hepatic ductular hypoplasia associated with characteristic facies, vertebral malformations, retarded physical, mental, and sexual development, and cardiac murmur. Journal of Pediatrics, 86, 63-71.

Antony, G., and Beveridge, J. (1975). Letter: Rickets in neonatal hepatitis. Archives of Disease in Childhood, 50, 406.

Belsey, R. E., De Luca, H. F., and Potts, J. T., Jr (1974). A rapid assay for $25-\mathrm{OH}$-vitamin $\mathrm{D}_{3}$ without preparative chromatography. Journal of Clinical Endocrinology and Metabolism, 38, 1046-1051.

Burmeister, W., Krämer, D., and Kirsch, W. (1972). Erste Erfahrung der Rachitisprophylaxe mit 25-HCC bei Frühgeborenen. Klinische Pädiatrie, 184, 190-200.

Daum, F., Rosen, J. F., Roginsky, M., Cohen, M. I., and Finberg, L. (1976). 25-Hydroxycholecalciferol in the management of rickets associated with extrahepatic biliary atresia. Journal of Pediatrics, 88, 1041-1043. 
Haddad, J. G., and Chyu, K. J. (1971). Competitive proteinbinding radioassay for 25 -hydroxycholecalciferol. Journal of Clinical Endocrinology and Metabolism, 33, 992-995.

Hepner, G. W., Roginsky, M., and Moo, H. F. (1976) Abnormal vitamin $\mathbf{D}$ metabolism in patients with cirrhosis. American Journal of Digestive Diseases, 21, 527532.

Kobayashi, A., Kawai, S., Utsunomiya, T., and Ohbe, Y. (1974a). Bone disease in infants and children with hepatobiliary disease. Archives of Disease in Childhood, 49, 641-646.

Kobayashi, A., Utsunomiya, T., Ohbe, Y., and Nagashima, Y. (1974b). Intestinal absorption of calcium and magnesium in hepatobiliary disease in infancy. Archives of Disease in Childhood, 49, 90-96.

Kobayashi, A., Utsunomiya, T., Kawai, S., and Ohbe, Y. (1976). Congenital biliary atresia: analysis of 97 cases with reference to prognosis after hepatic portoenterostomy. American Journal of Diseases of Children, 130, 830-833.

Long, R. G., Skinner, R. K., Wills, M. R., and Sherlock, S. (1976). Serum-25-hydroxy-vitamin-D in untreated parenchymal and cholestatic liver disease. Lancet, 2, 650-652.
Long, R. G., Meinhard, E., Skinner, R. K., Varghese, Z., Wills, M. R., and Sherlock, S. (1978). Clinical, biochemical, and histological studies of osteomalacia, osteoporosis, and parathyroid function in chronic liver disease. Gut, 19, 85-90.

Summerskill, W. H. J., and Walshe, J. M. (1959). Benign recurrent intrahepatic 'obstructive' jaundice. Lancet, 2, 686-690.

Wagonfeld, J. B., Nemchausky, B. A., Bolt, M., Horst, J. V., Boyer, J. L., and Rosenberg, I. H. (1976). Comparison of vitamin $D$ and 25-hydroxy-vitamin-D in the therapy of primary biliary cirrhosis. Lancet, 2, 391-394.

Yu, J. S., Walker-Smith, J. A., and Burnard, E. D. (1971). Rickets: a common complication of neonatal hepatitis. Medical Journal of Australia, 1, 790-792.

Correspondence to Dr Akio Kobayashi, Department of Paediatrics, National Children's Hospital, Taishido 3-35-31, Setagaya-ku, Tokyo 154, Japan.

Received 7 November 1978 